\title{
Radioimmunoassay of serum cortisol levels in leprosy patients with special reference to type I and type II reaction
}

\author{
$\mathrm{K}$ SAHA, ${ }^{*} \mathrm{~K}$ N RAO, ${ }^{*} \mathrm{~V}$ N SEHGAL, $\dagger \mathrm{S}$ GADI, \\ $\mathrm{V}$ K JAIN $\S$ \& A K CHAKRABARTY $\mathbb{T}$ \\ * Vallabhbhai Patel Chest Institute, University of Delhi, Delhi-110 \\ 007; † Maulana Azad Medical College and associated LNJPN and \\ GB Pant Hospitals, New Delhi; $\ddagger$ Hindusthan Copper Complex \\ Mines Hospital, Mosabani 832 104; § Department of Dermatology, \\ Medical College Hospital, Rohtak 124 001; and $\mid$ University College \\ of Medical Sciences, Ring Road, New Delhi-110 029, India.
}

\section{Accepted for publication 11 October 1984}

\begin{abstract}
Summary In the present paper, an attempt has been made to assess the adrenal cortical functions in leprosy patients, especially in LL cases and also in patients with type I and type II lepra reaction by estimating serum cortisol levels in them and comparing these results with those in healthy adults. Both the patient and control population belonged to a copper mining district in an eastern state of India.

Eighty leprosy patients including $23 \mathrm{LL}, 17 \mathrm{BL}, 3 \mathrm{BB}, 7 \mathrm{BT}$ and 30 patients with type I ( 10 cases) and type II ( 20 cases) lepra reactions formed the basis of this study. Forty-one age-matched normal adults from similar socio-economic status served as controls. The mean basal serum cortisol levels in 23 LL cases and 41 controls were 18.21 and $12.98 \mu \mathrm{g} / \mathrm{dl}$, respectively. Diurnal variation of serum cortisol level was studied in $4 \mathrm{LL}$ cases who showed normal circadian rhythm. Intramuscular injection of ACTH in another 4 patients ( $2 \mathrm{LL}$ and $2 \mathrm{BL}$ ) showed an increase of mean serum cortisol level from $14.75 \mu \mathrm{g} / \mathrm{dl}$ to $21.75 \mu \mathrm{g} / \mathrm{dl}$ after 30 min of challenge. Most interestingly, it was found that at the onset of type II lepra reaction the mean serum cortisol level increased to $17 \cdot 35 \mu \mathrm{g} / \mathrm{dl}$ and after remission of ENL its level decreased to $11.41 \mu \mathrm{g} / \mathrm{dl}$. The difference was statistically significant $(P<0.01)$. On the contrary, no such variation was found in patients with type I reaction.
\end{abstract}

\section{Introduction}

Leprosy is a chronic infective disease which not only involves skin and mucolis membrane but also endocrine organs.' The adrenal gland is not usually affected. Small nodules have been reported in zona faciculata and reticularis and also 
around the medullary veins. ${ }^{2 .}{ }^{3}$ Some studies have ${ }^{4-6}$ determined urinary 17 ketosteroids and 17 corticoids while another study ${ }^{7}$ evaluated the functional state of adrenals in leprosy by estimating serum cortisol levels. Lately reduced suppressor T-cells in ENL patients have been described. ${ }^{8,9}$ Also it is suggested ${ }^{10}$ that during stress there is raised cortisol level with increased percentage of helper-inducer-T-cells. It is therefore interesting to assess the adrenal function by estimating serum cortisol levels, for very little information is available in literature on this aspect, especially during lepra reaction. The present study focuses attention on multibacillary lepromatous and borderline lepromatous cases and also in patients during reaction and following clinical remission of reaction. It seems likely that it may throw some light on the role of the adrenal gland on the course of lepra reaction.

\section{Materials and methods}

Fifty multibacillary patients including 23 polar lepromatous (LL), 17 borderline lepromatous (BL), 3 borderline borderline (BB), and 7 borderline tuberculoid (BT) cases took part in this study, 37 were males and 13 females. The diagnosis of these patients was made on the basis of 5 group classification." Their age ranged from 12 to 65 years; and the duration of their illness varied from 1.5 to 25 years. None had any endocrine disorder. Dapsone was being administered to all of these patients. In addition 15 of them were receiving multiple drug therapy comprising clofazimine and rifampicin. ${ }^{12}$ Of these patients, $4 \mathrm{LL}$ male cases were subjected to excess diurnal rhythm of serum cortisol levels. Another 4 male cases ( $2 \mathrm{LL}$ and 2 $\mathrm{BL}$ ) were subjected to test endogenous cortisol production after adrenocorticotrophic hormone (ACTH) challenge. No patient was on corticosteroid therapy at the start of the test. To study the adrenal function during lepra reaction, 30 patients including 4 females were taken (Table 1). The diagnosis of the type of reaction was made on recognition of their well-formed clinical features. ${ }^{13}$ Their ages ranged from 15 to 70 years; and their duration of illness from 1 to 11 years. All these patients received corticosteroids to control their reaction. In addition 7 cases of LL and BL leprosy with type II reaction also received rifampicin. Remaining patients were on dapsone. Two samples of blood were collected from these patients, one at the onset of reaction and before administration of steroids; and the other at the clinical remission of reaction only after they were totally weaned of steroids. Forty-one healthy male volunteers of similar age range and socio-economic background and from the same area served as controls.

For estimating the basal serum cortisol level $5 \mathrm{ml}$ of blood was collected from each subject at 9 am. To study the circadian cortisol rhythm, paired blood samples were taken at 9 am and $6 \mathrm{pm}$. The adrenal cortical sufficiency during stress was assessed by the collection of paired samples before, and $30 \mathrm{~min}$ after, intramuscular injection of 40 units ACTH. 
Table 1. Histological types of the patients of type I and II lepra reactions

\begin{tabular}{ccc}
\hline & $\begin{array}{c}\text { Lepra } \\
\text { (no. of cases) }\end{array}$ \\
\cline { 2 - 3 } Histological type & Type I & Type II \\
\hline BT. & 4 & - \\
BB & 5 & - \\
BL & - & 10 \\
LL & $1^{*}$ & 10 \\
\hline Total & 10 & 20 \\
\hline * Histoid leprosy.
\end{tabular}

\section{SERUM CORTISOL DETERMINATIONS}

Serum cortisol levels were determined by radioimmunoassay using reagents purchased from Cambridge Medical Diagnostics Inc, USA.${ }^{14}$ Briefly, $25 \mu$ l of test serum samples were mixed with $100 \mu \mathrm{l}$ of ${ }^{125}$ I cortisol containing about $4 \mathrm{mci}$ of ${ }^{125}$ I in phosphate buffer ( $\mathrm{pH} 5.0$ ), bovine serum albumin and goat anti-rabbit gammaglobulin. Thereafter, $1 \mathrm{ml}$ of rabbit anti-cortisol serum in phosphate buffer, $\mathrm{pH} 5.0$ containing bovine serum albumin, rabbit gammaglobulin and a displacing agent were added to the mixture, incubated for $90 \mathrm{~min}$ at $37^{\circ} \mathrm{C}$, centrifuged, supernatant drained and the radioactivity in the precipitates was counted in a gammacounter (IC4702, Electronic Corporation of India).. The counts of the test samples were compared with those obtained with reference cortisol standards: $1,2,5,6,15,35$ and $75 \mu \mathrm{g} / \mathrm{dl}$.

\section{Results}

Table 2 shows the basal serum cortisol levels in normal subjects and leprosy patients. Although the mean serum cortisol level in patients with lepromatous leprosy $(18.21 \pm 16.82 \mu \mathrm{g} / \mathrm{dl})$ was higher than that in the normal $(12.98 \pm 6.43)$, the difference was not statistically significant. Table 3 shows the diurnal variations of serum cortisol levels in leprosy patients. It was found that the levels of the hormone in the morning samples were higher than that in the evening samples. Table 4 shows that ACTH injection could induce the steroidogenesis in lepromatous cases about $46 \%$ above their basal level after $30 \mathrm{~min}$ of the challenge.

The mean serum cortisol level in 10 patients at the onset of type I lepra 
Table 2. Basal serum cortisol levels in normal volunteers and leprosy patients

\begin{tabular}{|c|c|c|c|c|c|}
\hline \multicolumn{2}{|l|}{ Group } & Number & \multicolumn{3}{|c|}{$\begin{array}{c}\text { Basal serum cortisol } \\
\text { level } \mu \mathrm{g} / \mathrm{dl} \\
\text { Mean } \pm \mathrm{SD} \text { (range) }\end{array}$} \\
\hline \multicolumn{2}{|c|}{$\begin{array}{l}\text { A Normal subjects } \\
\text { B Leprosy patients }\end{array}$} & 41 & $12 \cdot 98 \pm 6.43$ & \multicolumn{2}{|c|}{$(2 \cdot 3-30)$} \\
\hline \multicolumn{2}{|c|}{$\begin{array}{l}\text { B Leprosy patients } \\
\text { (i) LL }\end{array}$} & 23 & $18 \cdot 21 \pm 16 \cdot 82$ & \multicolumn{2}{|c|}{$(5 \cdot 8-75)$} \\
\hline (ii) $\mathrm{BL}$ & & 17 & $12 \cdot 30 \pm 6 \cdot 65$ & \multicolumn{2}{|c|}{$(2 \cdot 9-30)$} \\
\hline (iii) $\mathrm{BB}$ & & 3 & $16 \cdot 00 \pm 3 \cdot 56$ & \multicolumn{2}{|c|}{$(13-21)$} \\
\hline (iv) $\mathrm{BT}$ & & 7 & $10 \cdot 21 \pm 3 \cdot 07$ & \multicolumn{2}{|c|}{$(6-16 \cdot 5)$} \\
\hline \multicolumn{6}{|c|}{$\begin{array}{l}\text { Statistical evaluation. } \\
t \text { test between } A \text { and } B(i):>1.43 \text { (not significant). }\end{array}$} \\
\hline \multicolumn{6}{|c|}{$\begin{array}{l}\text { Table 3. Circadian rhythm of serum cortisol levels in } \\
\text { lepromatous patients }\end{array}$} \\
\hline \multirow[b]{2}{*}{ Leprosy patient } & \multirow[b]{2}{*}{ Type } & \multirow{2}{*}{\multicolumn{2}{|c|}{ Duration of illness }} & \multicolumn{2}{|c|}{$\begin{array}{l}\text { Serum corti- } \\
\text { sol level } \mu \mathrm{g} / \mathrm{dl}\end{array}$} \\
\hline & & & & $9 \mathrm{am}$ & $6 \mathrm{pm}$ \\
\hline TS & BL & & 5 & 18 & $7 \cdot 4$ \\
\hline RL & BL & & 7 & 13 & 8 \\
\hline SM & LL & & 2 & 23 & 17 \\
\hline SD & BL & & 8 & 16 & 10 \\
\hline
\end{tabular}

Table 4. Serum cortisol level in lepromatous patients before and after ACTH challenge

\begin{tabular}{ccccc}
\hline & & & \multicolumn{2}{c}{ Serum cortisol level $\mu \mathrm{g} / \mathrm{dl}$} \\
\cline { 3 - 5 } Leprosy patient & Type & Duration of illness & $\begin{array}{c}\text { Before ACTH } \\
\text { injection }\end{array}$ & $\begin{array}{c}0.5 \mathrm{hr} \text { after } \\
\text { ACTH injection }\end{array}$ \\
\hline LG & LL & $1 \frac{1}{2}$ & 12 & 18 \\
DM & LL & 3 & 10 & 15 \\
KB & BL & 3 & 18 & 27 \\
KM & BL & 1 & 19 & 27 \\
\hline & Mean & & 14.75 & 21.75 \\
\hline
\end{tabular}


Table 5. Serum cortisol level in leprosy patients with type I and type II reactions

\begin{tabular}{|c|c|c|c|c|c|}
\hline \multirow[b]{2}{*}{ Group } & \multirow{2}{*}{$\begin{array}{c}\text { Number of } \\
\text { patients }\end{array}$} & \multicolumn{2}{|c|}{$\begin{array}{l}\text { Serum cortisol level } \mu \mathrm{g} / \mathrm{dl} \\
\text { Mean } \pm \mathrm{SI} \text { ) (range) }\end{array}$} & \multicolumn{2}{|c|}{$\begin{array}{l}\text { Statistical evaluation } \\
\text { (A) and (B) }\end{array}$} \\
\hline & & (A) At onset & (B) At remission & 't'value & 'P'value \\
\hline $\begin{array}{l}\text { (a) Patients with type } \\
\text { I reaction }\end{array}$ & 10 & $\begin{array}{r}11 \cdot 04 \pm 4 \cdot 91 \\
(2 \cdot 3-18 \cdot 0)\end{array}$ & $\begin{array}{r}10 \cdot 1 \pm 3 \cdot 92 \\
(6 \cdot 2-18 \cdot 0)\end{array}$ & Not done & Not done \\
\hline $\begin{array}{l}\text { (b) Patients with type } \\
\text { II reaction }\end{array}$ & 20 & $\begin{array}{l}17 \cdot 32 \pm 15 \cdot 30 \\
(1 \cdot 6-60)\end{array}$ & $\begin{array}{l}11 \cdot 41 \pm 5 \cdot 90 \\
(1 \cdot 6-30)\end{array}$ & $3 \cdot 27$ & $<0.01(\mathrm{~S})$ \\
\hline $\begin{array}{l}\text { Statistical evaluation: } \\
\text { (a) and (b) } \\
\text { ' } t \text { ' value between a and b } \\
\text { ' } P \text { ' }\end{array}$ & & $\begin{array}{c}3 \cdot 14 \\
<0 \cdot 01(\mathrm{~S})\end{array}$ & Not done & & \\
\hline
\end{tabular}

No increase of serum cortisol level was seen in type I reaction at onset; in contrast a significant elevation of the hormone level was found in type II reaction during attack.

$\mathrm{S}=$ Significant.

reaction $(11.04 \pm 4.91 \mu \mathrm{g} / \mathrm{dl})$ was not statistically different from that at remission $(10 \cdot 1 \pm 3.92 \mu \mathrm{g} / \mathrm{dl})$. On the contrary the mean serum cortisol level in 20 patients at the onset of type II reaction $(17 \cdot 32 \pm 15 \cdot 30 \mu \mathrm{g} / \mathrm{dl})$ was significantly higher $(P$ value $<0.01)$ than that at remission $(11.41 \pm 5.90 \mu \mathrm{g} / \mathrm{dl}(P<0.01)$ (Table 5). However after remission the levels are comparable in both types of reaction. On further analysis of the individual hormone levels, it was found that 7 out of 10 patients at the onset of type I reaction showed serum cortisol level within the normal mean basal level $(12.98 \mu \mathrm{g} / \mathrm{dl})$, while 10 out of 20 patients at the onset of type II reaction showed higher than the mean normal levels. Statistical analysis was performed to evaluate the diagnostic efficacy of serum cortisol level to differentiate type I and type II reactions, taking normal mean serum cortisol level at $13 \mu \mathrm{g} / \mathrm{dl}$. The values above this level were taken as raised levels.

Chi square analysis

\begin{tabular}{lcc}
\hline $\begin{array}{c}\text { Serum } \\
\text { cortisol } \\
\text { level }\end{array}$ & $\begin{array}{c}\text { Type I } \\
\text { reaction } \\
\text { (\% patients) }\end{array}$ & $\begin{array}{c}\text { Type II } \\
\text { reaction } \\
(\% \text { patients })\end{array}$ \\
\hline Raised & 30 & 50 \\
Normal or below normal & 70 & 50 \\
\hline
\end{tabular}

Chi square was found to be $8.33(P<0.01)$. 


\section{Discussion}

The clinical manifestations of chronic adrenal insufficiency, regardless of cause, are attributable to deficiencies of cortisol (glucocorticoid) and aldosterone (mineralocorticoid) which are the principal secretions of the adrenal cortex. One common form of adrenal insufficiency deserves special comment. Large doses of cortisone and related glucocorticoids are often used in asthma, various autoimmune diseases and lepra reaction. When such treatment is extended beyond 4 or 5 weeks, suppression of cortisol releasing factor and ACTH secretion ensues. If the steroid is then abruptly discontinued, the hypothalamic pituitary axis is unable to respond normally to the low circulatory cortisol level. ${ }^{15}$

Conflicting data regarding the adrenal cortical function in patients of lepromatous leprosy are found in other studies. One ${ }^{16}$ reported normal circulating serum cortisol levels in $11 \mathrm{LL}$ patients $(7-12 \mu \mathrm{g} / \mathrm{dl})$ and indicated that further study on the subject would not be worthwhile. However, recently another report ${ }^{7}$ studied hydrocortisone production by 36 lepromatous patients after insulin load and found a paradoxical type of hormone production in 23 cases. Their data indicated markedly exhausted hydrocortisone producing function of the adrenal cortex, especially in active lepromatous diseases.

We found the radioimmunoassay of serum cortisol level by double antibody technique to be very accurate and specific. The basal level of serum cortisol (at $9 \mathrm{am}$ ) in our patients of all histological types was never below that observed in the normal controls (Table 2). This observation is parallel to that of another study. ${ }^{16}$ Also Table 3 provided evidence of normal circadian rhythm in the patients. Further, ACTH injections in these patients could induce increased steroidogenesis in them (Table 4). A normal cortisol response to ACTH injection causes a rise of at least $7 \mu \mathrm{g} / \mathrm{dl}$ above basal cortisol levels at $30 \mathrm{~min} .{ }^{17}$ These data, therefore, lend support to the functioning adrenal cortex in our patients. The mean serum basal cortisol level in the LL patients of Balybin \& Nazarov ${ }^{7}$ was also higher $(32.63 \pm 1.53 \mu \mathrm{g} / \mathrm{dl})$ than that in their normal subjects $(25.12 \pm 2.36) \mu \mathrm{g} / \mathrm{dl})$. It is noteworthy that the serum cortisol level in normal Russian subjects $(25 \cdot 12$ $\mu \mathrm{g} / \mathrm{dl}$ (mean) with a range of 7.45 to $37.24 \mu \mathrm{g} / \mathrm{dl}$ ) is higher than that in normal Indian individuals $(12.98 \pm 6.43 \mu \mathrm{g} / \mathrm{dl}$ ) (Table 2$)$ as well as in North Americans (with a mean of $12.4(5-25 \mu \mathrm{g} / \mathrm{dl}){ }^{17}$ This difference might be due to climatic and/or nutritional variations between these two groups of populations. Balybin \& Nazarov ${ }^{7}$ studied cortisol production under insulin load in LL patients and observed a paradoxical type of response. In contrast we studied the adrenal cortical function in our cases by ACTH load and found stimulation of the adrenals. Thus, the results of the 2 studies might not be comparable. As far as we know this is the first study of serum cortisol level in the reactional state of leprosy patients. Curiously, no change of the serum cortisol level was observed in type I lepra reaction, while at the onset of type II lepra reaction, the mean serum cortisol level increased and following remission, it touched normal levels (Table 5). Out of 
20 lepromatous cases with type II reaction, serum cortisol level decreased in 13 patients, while it increased in 6 and remained stationary in 1 (Fig. 1). The histoid case most probably represented relapse during a period of non-treatment or dapsone resistance. His nodules became red, swollen and reactivated, which was diagnosed as reversal reaction. Earlier Ridley described exacerbation of histoid nodules which were characterized by the presence of epitheloid cells. ${ }^{18}$

Thus, observed decrease of serum cortisol level after clinical remission may be partially due to the withdrawal of prednisolone therapy given to all with type II reaction. It is known that radioimmunoassay of cortisol cross reacts with prednisolone by $17 \%$ (manufacturer's literature). ${ }^{14}$ However this explanation is unable to explain no change of serum cortisol level in patients with type I reaction

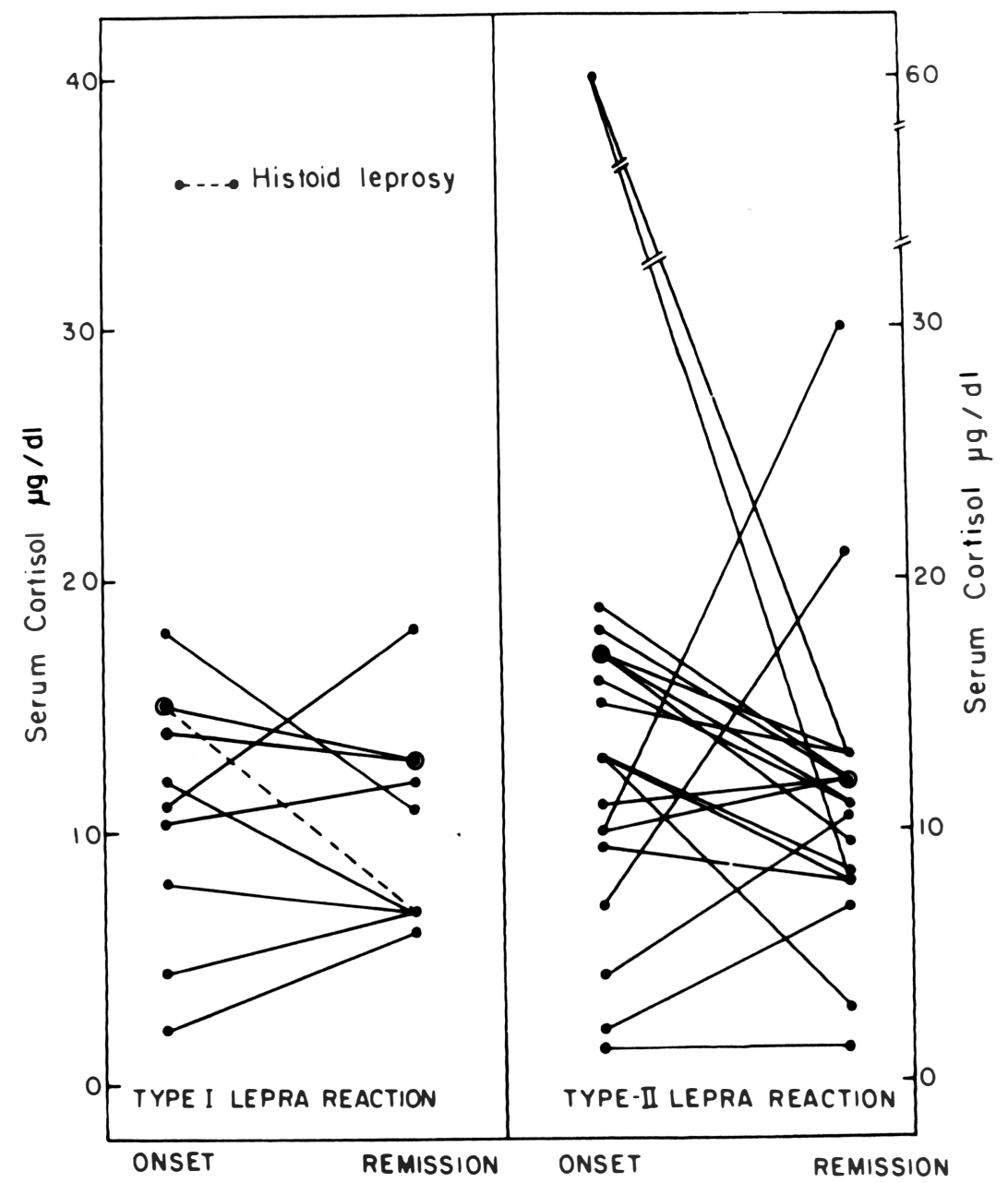

Figure 1. Serum cortisol levels in patients with type I and type II lepra reactions are shown at onset and after remission. 
(Table 4), who also received prednisolone. One study ${ }^{10}$ has suggested that during any psychological stress there was an increase in the percentage of OKT4 (helper-inducer $\mathrm{T}$ lymphocytes) along with increased serum cortisol concentration. Other studies ${ }^{8,9}$ have found reduced suppressor $T$ cells in ENL patients compared to normal controls and there was no significant effect on T-lymphocyte subpopulation during chemotherapy of BT patients. However the fact that the $T_{H}$ level rises does not necessarily mean that $T_{\mathrm{S} / \mathrm{C}}$ fall. Nevertheless the 3 following separate observations are valid: (a) $\mathrm{T}_{\mathrm{S} / \mathrm{C}}$ falls in ENL patients; (b) $\mathrm{T}_{\mathrm{H}}$ rises with raised cortisol level; and (c) cortisol level rises in ENL patients.

It is thus postulated that those patients who showed increase of serum cortisol levels, even after clinical remission of type II lepra reaction, might go into relapse because they were still in stress and might have a decreased percentage of suppressor $\mathrm{T}$-lymphocytes. One study ${ }^{7}$ has also suggested that lepromatous patients with a history of relapse should be further studied because they are vulnerable to glucocorticoid deficiency during stress. Leprologists often encounter sudden onset of lepra reaction in lepromatous cases during stress such as cold climate, infections, etc. At present, it is difficult to differentiate type I and type II reactions either clinically or by laboratory tests. Only histological examination of biopsy of the reaction nodule can distinguish the 2 lesions. Hopefully, serum cortisol levels of the patients at the onset of reaction may be helpful to differentiate type I and type II reactions. However, a wide variation of the serum cortisol levels among individual patients with reaction, warrants further study in more cases to firmly establish the role of serum cortisol as a diagnostic aid of types of lepra reaction.

\section{Acknowledgment}

The authors are most grateful to Mr P Hemchandran, General Secretary, Mr K G Nambiar, Administrative Officer, Singhbhum Navjivan Niketan, Ghatsila, Bihar; Dr P K Purkayastha, Chief Medical Officer, Indian Copper Mines Hospital, Mosabani, Bihar, for their help in carrying out the work. Partial financial assistance from the Indian Council of Medical Research, New Delhi is acknowledged.

\section{References}

I Cochrane RC, Davey TF. Leprosy in theory and practice. Bristol, UK: John Wright and Sons Ltd. 1964. pp. 190-204.

2 Mitsuda K. The significance of the vacuole in the virchow lepra cells and the distribution of lepra cells in certain organs. In Leprosy in theory and practice. Cochrane RC, Davey TF (eds), Bristol, UK: John Wright and Sons Ltd. 1964. p. 192. 
${ }^{3}$ Desikan K V, Job CK. A review of postmortem findings in 37 cases of leprosy. Int J Lepr, 1968; 36: 32-44.

${ }^{4}$ Goldgraber MB, Sulman FB. Adrenal cortical dysfunction in leprosy. Int J Lepr, 1964; 37: 351-8.

${ }^{5}$ Hardas UD, Saoji RG. 17-Ketosteroids in Leprosy. Int J Lepr, 1976; 43: 1-4.

${ }^{6}$ Balakrishnan S, Ramanujam K, G Ramu. Adrenocortical function tests in lepra reactions. Indian Journal of Med Res, 1974; 62: 1166-70.

7 Balybin ES, Nazarov KZ. Hydrocortisone production in leprosy patients with insulin load. Int $J$ Lepr, 1953; 51: 18-20.

${ }^{8}$ Mshana RN, Haregewoin A, Harboe M, Belehu A. Thymus dependent lymphocytes in leprosy. I. T-lymphocyte subpopulations defined by monoclonal antibodies. Int J Lepr, 1982; 50: 291-6.

9 Mshana RN, Haregewoin A, Belehu A. Thymus dependent lymphocytes in leprosy. II. Effect of chemotherapy on T-lymphocyte subpopulations. J Clin Incest, 1982; 2: 69-74.

11) Kronfol Z, House JD. Depression Cortisol and immune function. Lancet, 1984; i: 1026.

1 Ridley DS, Jopling WH. Classification of leprosy according to immunity. A five group system. Int J Lepr, 1966; 34: 255-73.

12 WHO Study Group. Chemotherapy of leprosy for control programmes. Technical Report Series. No. 675. WHO: Geneva, 1982.

13 Jopling, WH. Handhook of leprosy, 2nd edn. London: Heinemann, 1978. p. 66-74.

${ }^{14}$ Cambridge Medical Instruments Inc. Ma USA. Protocol for the Radioimmunoassay of cortisol. 125 I. 1983.

15 Burns TW. In Pathologic physiology. Mechanisms of disease. 6th ed. Sodeman WA, Sodeman TM (eds), Pennsylvania, USA: WB Saunders, 1981. pp. 1023-30.

16 Rolston R, Mathews M, Taylor PM, Koshy B. Hormone profile in lepromatous leprosy. A preliminary study. Int J Lepr, 1981. 49: 31-6.

17 Wagner RL, White PF, Kan PB, Rosenthal MH, Feldman D. Inhibition of adrenal steroidogenesis by the anaesthetic etomidate. New Eng J Med, 1984; 310: 1415-21.

18 Ridley DS. Reactions in leprosy. Lepr Rev, 1969; 40: 77-81. 